\title{
SCHOOL-BASED MENTORING FOR PROFESSIONAL DEVELOPMENT OF INCLUSIVE SCHOOL TEACHERS
}

\author{
Ženija Bērziņa \\ Daugavpils University, Latvia
}

\begin{abstract}
Because of the importance and the complexity of inclusive education, the implementing of a new teaching method in fifteen schools of four regions of Latvia was integrated with school-based teacher mentoring in a two-year project. A new method of teaching basic concepts for children with learning disabilities was a crucial part of in-service teacher training mentoring programme. This paper illuminates mentors' and teachers-mentees' perceptions on the impact of mentoring on their teaching at the primary school level. Data collected by the means of self-evaluation includes teachers' and their mentors' views on the role of mentoring and teachers' collaboration in teachers' professional development and inclusion of children with special needs. The results of the study show that mentoring and collaboration are pre-conditions for successful teachers' professional development, which creates, in its turn, a favourable basis for enhancement of inclusive education programmes.
\end{abstract}

Key words: mentoring, professional development, inclusive education

\section{Introduction}

In the recent international and local research, most teachers express their belief that inclusion of children with special needs is possible. At the same time, many of them are not sure if the general classroom is the best place for those children, if special classrooms must be organized for them in the general schools. They consider that celebrations, sports events and sightseeing are the best ways to include the disabled children in school or class activities. One of the most common arguments against inclusion of children with special needs in the general classroom is the lack of knowledge and skills for teaching them (Scruggs, Mastropieri, \& McDuffie, 2007; Nīmante, 2008). Numerous studies also show that inclusion is directly connected not only with teachers' beliefs, knowledge and skills, and their continuous professional development, but also depends on collaboration (Bricker, 1995, 2000; Ainscow, 2003; Hamre \& Oyler, 2004; Bourke \& Carrington, 2007; Florian, 2008). Fullan (1998) states that "student achievement increases substantially in schools with collaborative 
work cultures that foster a professional learning community among teachers and others" ( $\mathrm{p}$. 8).

It should be noted that in Latvia the requirements for teachers' in-service education set by the Ministry of Education and Science are minimal, and they cannot meet the needs of teachers' professional development in the conditions of educational reforms. However, in collaborative schools, teachers can draw from their own and their colleagues' experience, knowledge and understanding. In collaborative schools, teachers' topical needs can be met. Nowadays, teachers' professional development cannot be realized based only on external resources. The school-based professional development during a teacher's career is a good solution (Carrington \& Robinson, 2004). Moreover, Wang and Odell (2002) state that "...the best staff development is not when "experts" teach "novices", it is much more when continuous sharing and dialogue happens (p. 481). In the conditions of the crucial need to prepare teachers to work in inclusive classrooms, and of the limited financial resources for teacher in-service training, teachers' collaboration becomes even more crucial.

One of the successful ways to enhance collaboration and to improve teachers' competences is school-based mentoring (Wang \& Odell, 2002; Tillman, 2005). The research demonstrates the extremely important role of mentoring in the periods of change, which requires different thinking and approaches in education. Mentoring is particularly helpful for the professional development in the organizations where human relationships, support and learning have the central role for organizational growth. Undoubtedly, schools are organizations of this kind. As stated by Hargreaves and Fullan (2000), mentoring has enormous but not fully used potential to support continuous school change.

In his book "Experience and education" (1963), which was first published in 1938, Dewey emphasized the social character of learning. An individual participates in activities oriented to social participation; therefore, people need support from others in their learning. The idea of learning together and school-based mentoring is rooted in Vigotsky's (2002) socio-cultural approach to human development. Vigotsky (2002) determined that we learn better when we are involved in a dialogue with those who challenge our present knowledge and structure our future learning. Based on the social aspects of learning and research in learning organizations, the researchers' interest about mentoring has increased. Wildman, Magliaro, Niles and Niles (1992) state that mentor's role is less about teaching, it is more about understanding of the context of the mentee's learning and guiding of the mentee's learning. "Just as good teaching, mentoring should be defined from the perspective of both parts" (Wildman et al., p. 212). Fibkins (2002) concludes that mentoring is based on adults' ability to develop and learn, and that their development can be influenced by different means that are supportive and challenging. The mentor structures the mentee's learning, shares his/her knowledge and supports the mentee's effort, but, at the same time, he/she does not protect the mentee from failure (Jonson, 2008). Freire (1997) emphasizes that the mentee's desire to attain insight and distinguish new opportunities with pleasure, which is crucial for the success of mentoring. He (Freire, 1997) also considers that it is important to risk. With support, critical thinking and reflection the mentor encourages the mentee to explore the benefits of risk-taking and learning in the process of change. According to Hargreaves (1992), "[t]rust which appears through collegial sharing and mutual support results 
in risk taking on higher level, and in teachers' inner necessity to continuous improvement as an obligation of the teacher's profession" (p. 80).

Mentoring is a new direction in teacher professional development system in Latvia launched in the beginning of 2000s. Since then, a few projects have been focusing mainly on mentoring in pre-service teacher practicum by in-service teachers and on mentoring in in-service teacher professional development by university or other external experts on particular subjects, for instance, the English language, mathematics and science teachers. There have been very few programmes which focused on school-based mentoring where the mentor works at the same school and supports the professional development of his/her colleagues.

The school-based mentoring programme which was implemented in fifteen schools within this study included two main components: (1) Nyborg's concept teaching strategy and (2) mentoring. To support the teachers in their professional development, the acquisition of the new concept teaching strategy was merged with school-based pair mentoring. The concept of teaching strategy is grounded in a conceptual teaching theory (Lebeer, Sonnesin, Roth, \& Pokorna, 2006). Lebeer et al. (2006) view learning as a meaningful reflexive activity rather than mechanical memorization of separate phenomena and formulas. The concept-based teaching strategy promotes conscious and meaningful learning; thus, children with learning disabilities are able to transform and utilize more varied concepts in various conditions and situations. Teachers who are ready to try new ideas and methods, take risks and experiment need to feel supported and empowered by their colleagues in the school (Salīte, Mičule, Kravale, Iliško, \& Stakle, 2007). Therefore, school-based mentoring was introduced to help teachers implement the new strategy.

\section{Methods}

School based mentoring is a way to pro-actively and purposefully enhance inclusion, overcome teacher isolation and promote their collaboration. Moreover, it is a way of active participation, learning and research. Within this study, the mentoring programme was implemented through action research metholodolgy, which was aimed at investigating the impact of school-based pair mentoring for teacher professional development and for the quality of inclusion and cognitive education of children with special needs. The particular value of action research is that it is possible to direct the change process from within (Schein, 2004; Reason \& Bradbury, 2008; Salīte, 2009; Salīte, Gedžūne, \& Gedžūne, 2009). In this research, the action research was from the classrooms where children with special needs learned together with their peers.

38 primary school teachers and their 38 mentors participated in the action research. The selection criteria of the mentees - primary school teachers - were the following: (1) they should have children with special needs in their classrooms; (2) they should have an interest to acquire and implement the new teaching strategy in their classrooms as well as an interest in action research. The mentors represented different staff member groups: more experienced teachers in the field of inclusion, special educators, a psychologist and deputy heads. It is extremely important to provide continuation of inclusion for children with spe- 
cial needs from inclusive preschool classrooms to inclusive primary classrooms. Therefore, the reason why primary school teachers were the focus group of the action research is because too many children who have been included in pre-schools continue their learning in special schools. Some school principals and other teachers who were not directly involved in the mentoring programme were also participants of the action research. Thus, there were 90 research participants in total.

Since learning is the foundation of mentoring, Knowles's theory of adults learning was applied in the development of the mentoring programme (Knowles, Holton III, \& Swanson, 2005). The following principles were set: (1) the programme must integrate theory and practice; (2) it must correspond to the needs of teachers and schools in the context of inclusive education; (3) the programme should be focused on school-based pair mentoring. The following methods were used to explore the effectiveness of the mentoring programme on teacher professional development and its applicability to introduce in other schools that implement inclusive education programmes: (1) teachers and school directors' questionnaires at the beginning of the study; (2) teachers and mentors' self-evaluation at the end of the first and the second year of the study; (3) focus group discussions and interviews in the end of the action research. This paper describes the results of only one of the applied research methods - the teachers and mentors' self-evaluation. In a qualitative research, every social activity is associated with participants' explanations and interpretations. In this study, teachers' authentic evaluation of their behaviour in the classroom, their experience of interactions with students in the classroom and with colleagues in the school was the object of the self-evaluation. Both quantitative and qualitative methods were applied for data analysis.

\section{Discussion}

At the end of the first and second year of the action research, the mentors and the mentees performed self-evaluation. In the first year, 15 mentors and 15 mentees participated in selfevaluation, in the second year -23 mentors and 23 mentees. Thus, all participants of the peer mentoring performed self-evaluations. They were invited to evaluate the impact of the mentoring programme in four main directions: (1) enhancement of inclusion of children with special needs, (2) benefits of the mentoring programme, (3) difficulties and (4) future perspectives. The aim of this paper is to describe the results of the data analysis connected with teacher professional development, the increase of the number of included children and improvement of their learning, and the development of collaboration among teachers. To evaluate teachers' and mentors' knowledge and skills in concept teaching, the ranking between "low-medium-high-very high" was offered. It was addressed by several questions, which required descriptive answers. Thus quantitative and qualitative data were collected.

The summary of the data collected from the mentors indicates that they are rather selfcritical in the evaluation of their skills and knowledge of using Nyborg's concept teaching strategy at the end of the first and the second year of the study. They are also self-critical in the evaluation of their skills and knowledge in helping teachers to implement the new strategy (Table 1). 
An interesting tendency, which appears in mentors' self-evaluation, is that the average estimation of the mentoring skills is considerably lower at the end of the second year of the study than at the end of the first year. This may be explained by the fact that, in the first year, mainly special education teachers, deputy directors, psychologist and experienced teachers were mentors; thus, it was easier for them to accept and act in the role of mentor.

Table 1. Mentors' self-evaluation (ranking 1-4)

\begin{tabular}{lcccccc}
\hline Indicator & year & low & medium & high & very high & nr average \\
\hline Understanding of Nyborg's & 2009 & & 10 & 5 & 15 & 2.33 \\
\cline { 2 - 8 } concept teaching strategy & 2010 & & 16 & 7 & 23 & 2.30 \\
\hline \multirow{2}{*}{\begin{tabular}{l} 
Mentoring skills \\
\cline { 2 - 8 }
\end{tabular}} & 2009 & 1 & 10 & 4 & 15 & 2.87 \\
\hline
\end{tabular}

Conversely, in the second year the mentors who joined the action research were mostly teachers, and they may have been too self-critical in self-evaluation. An interesting tendency, which appears in mentors' self-evaluation, is that the average estimation of the mentoring skills is considerably lower at the end of the second year of the study than at the end of the first year. This may be explained by the fact that, in the first year, mainly special education teachers, deputy directors, psychologist and experienced teachers were mentors; thus, it was easier for them to accept and act in the role of mentor. Conversely, in the second year the mentors who joined the action research were mostly teachers, and they may have been too self-critical in self-evaluation. The mentees have been even more cautious than mentors in assessing their skills and knowledge of Nyborg's teaching strategy both at the end of the first and the second year of the study (Table 2). The teaching strategy offered within the mentoring programme is quite complex. As stated by the teachers, it asks them "to think about the concepts" and "to repeat and to increase my theoretical knowledge in psychology”.

Table 2. Teachers' (mentees') self-evaluation (ranking 1-4)

\begin{tabular}{lccccccc}
\hline Indicator & year & low & medium & high & very high & nr & average \\
\hline $\begin{array}{l}\text { Understanding of } \\
\begin{array}{l}\text { Nyborg's concept } \\
\text { teaching strategy }\end{array}\end{array}$ & 2009 & 11 & 4 & & 15 & 2.27 \\
\hline $\begin{array}{l}\text { Impact of mentoring } \\
\text { on the improvement } \\
\text { of learning of children 2010 }\end{array}$ & 1 & 19 & 4 & & 23 & 2.17 \\
with special needs & & 5 & 7 & 1 & 13 & 2.69 \\
\hline
\end{tabular}

Comparing how the mentors have evaluated their mentoring skills with the mentees' selfevaluation of the impact of mentoring on the improvement of learning of children with special needs, the mentees have valued the mentors' help more than the mentors valued themselves. It may be because the teachers connect the mentors' help with the improvement of children's learning more directly. 
It may be explained by two main reasons why teachers and mentors evaluated their knowledge and understanding of Nyborg's concept teaching lower than average. Firstly, the respondents have been rather self-critical; secondly, the strategy itself is truly innovative and requires meaningful and intensive learning. In fact, these difficulties promoted mutual learning. The participants were forced to risk and experiment, and resolve problems creatively. When asked to evaluate the benefits of the mentoring programme for teaching children with special needs at the end of the first year, the teachers characterize them rather generally: "It's a new method"; "More attention is paid to using the correct language"; "It's a possibility to get to know and try out a new method in practice", or the teachers reduced the use of the new strategy to the individual child with special needs teaching. They state that "the method can be used at individual speech therapy activities"; "the method is very adequate for individual work". At the end of the second year of the mentoring programme, the teachers and the mentees were more focused on understanding and beliefs connected to the benefits of the programme. The influence of mentoring on the school values is more distinguished. Teachers have a better "understanding about differences in students' knowledge and skills"; "belief that, as a result of continuous and patient learning, children with learning disabilities are able to learn in general classrooms" and "concept teaching is incorporated in everyday work". At the end of the mentoring programme, it was typical that teachers spoke of what they had gained, they paid particular attention to the achievements of children with disabilities. They used various arguments to prove the positive effect on children's learning: "Children have become more easy, they are more involved in the whole class activities"; "This method makes easier the perception of the taught content"; "The students can already read short words"; "Children's development is seen"; "Children understand concepts better"; "...participate willingly"; "Children's interest and motivation has increased". On the one hand, the more frequent use of the singular form "child" when speaking about children indicates that the new methodology was most applied in individual work with children with disabilities. On the other hand, it shows that teachers observe the development of the children and seek the best solutions for their teaching and learning.

The mentors value the benefits of the mentoring programme for the whole school more often. Despite that, mentors have pointed out considerable difficulties in implementing the new teaching strategy because of its novelty and complexity. They state that its implementation in teaching children with special needs has resulted in "more clarity of work with children who have learning difficulties" and in "a more interesting organization of lessons". "New knowledge" and "getting to know the new strategy" have been valued. It testifies that the correct content has been chosen for learning within the mentoring programme. The mentors have also paid more attention to collaboration and valued it as beneficial for the whole school. They mention "more close contacts and collaboration with teachers"; "successful cooperation with the support staff" and "with students and parents". Collaboration promotes "sharing of experience, problem solving together" and "a possibility to meet supporters of the same ideas in the school", with whom "it is possible to discuss the results of the teaching". In their turn, the mentees have mentioned collaboration surprisingly little, and mostly in the context of "sharing of experience with colleagues". Interpretation of data about the benefits of the mentoring programme elucidates that, to acquire and 
apply the innovative teaching strategy, teachers and mentors required more learning, and that promoted more interest in varied children's with special needs learning. The formulations, which are used in self-evaluations - "understanding", "belief", "attitude" - point towards conscious and purposeful use of the new knowledge.

One third of the mentors at the end of the first year of the action research and one fourth at the end of the second year have mentioned most often the lack of time as the difficulty to fulfil their responsibilities. Many of them connect this problem more with teachers' lack of time, presuming that "teachers have too little time for individual work with children", "because of the lack of time, it is not possible to apply this method with full value". The lack of time is also most often cited difficulty in implementing the new teaching strategy mentioned in the teachers' self-evaluations. Though the concept of teaching strategy may be used for an individual, small groups and the whole class teaching, teachers complain that "there is too little time for individual work".

Nyborg's concept teaching strategy has caused "the sense of insecurity - am I doing it correctly?" and "I have to think of the concepts". However, as one teacher writes: "It was most important to accept and to try it myself". The mentors have recommended that, to better use the new teaching strategy, "it would be more effective if the special education teacher was introduced more to the concept teaching strategy and could work with the child individually". Despite the difficulties to fulfil their role as mentors, some mentors experimented with themselves to apply the new method not only for teaching the children of the primary school age, but also for the older students who had problems in learning concepts. Thus, the implementation of the new strategy required thoughtful and serious learning. Without the challenges and problem solving, and if the programme were not connected with deep changes in the understanding of teaching and in the everyday teaching practice, the mentoring would lose its main function - support for learning and development of the mentee.

The interpretation of the data concerning the future tasks indicate the sustainability of the school-based mentoring. At the end of the first year of the mentoring programme, the mentors mostly plan what they will do to support their mentee. Conversely, at the end of the second year, all mentors' plans are aimed at the broader school community "in cooperation with colleagues" and "to support the other teachers". After the first year, the mentors act as change agents mostly by "raising interest", "introduction" and "encouraging". Conversely, after the second year, they foresee themselves more as facilitators of the others' learning, which is one of the most essential roles of a mentor - to be a model for the learner. The data collected about the teachers' future plans show that they are going to continue to implement the concept teaching strategy. Moreover, they intend to use it more creatively and variedly. Within the action research, the teachers learned how to use the strategy in teaching mathematics. Already during the two-year period of the mentoring programme, teachers started to use it in teaching geography, house-keeping, music. They plan to try this strategy also in teaching foreign languages and science. The teachers plan to observe and evaluate the process and the achievements of children's learning more accurately and regularly. They have set tasks for their future professional development. The teachers want to "classify concepts in a system when planning a lesson", "to document children's development", "to analyse the results of teaching concepts at the end of the school year". Cer- 
tainly, these expressions contain classroom research elements and show the higher level of creative use of the strategy, which the teachers have acquired during the mentoring program. Both the mentees and the mentors plan to continue their learning and use the new strategy more effectively: "to read through all materials of the courses more carefully", "to read the theoretical materials once more", "to improve knowledge in Nyborg's teaching strategy", "to clarify the unclear questions" and "to continue to acquire Nyborg's theory and to prove... that it is possible to reach good results by it". They also expect that the other teachers will share their experience.

\section{Conclusion}

One of the aims of the mentors and teachers' self-evaluation was to evaluate the impact of the mentoring programme on the inclusion of children with special needs and the improvement of their learning. The two year period of the action research corresponded with two school years. Within that period, the number of children with disabilities had almost doubled. Though there may be more reasons for such a remarkable increase, for instance, the change of the school financing (the principle "money follows the child" had been introduced). However, the remarkable increase of the included children also testifies to the positive effect of the mentoring programme. The enrichment of teachers by a new teaching strategy has echoed in the increase of their sense of security to include children with special needs in their classrooms.

The interpretation of the authentic qualitative data revealed that due to the schoolbased mentoring through teacher collaboration, learning and self-reflection, the inclusion of children with special needs becomes more meaningful. All participants of the action research have valued mentoring as a positive experience in their professional development. But teachers' professional development and collaboration become meaningful only if they serve to better the learning of their students. Though both respondent groups have been rather self-critical and careful in evaluation, it was valued unequivocal that the achievements of children with special needs had improved (Figure 1).

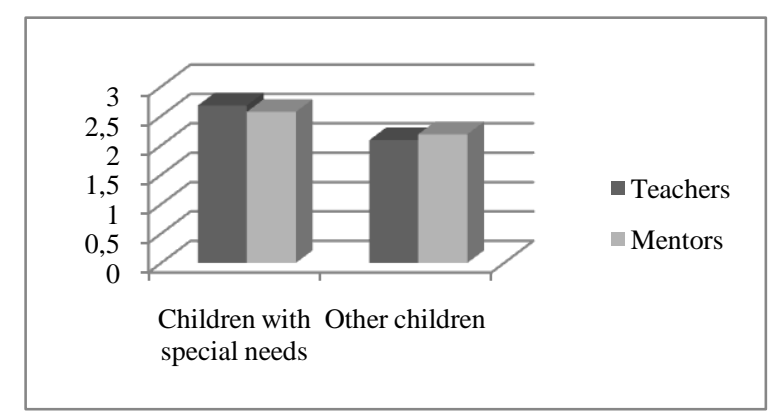

Figure 1. Teachers and mentors' views on the impact of the mentoring on students' achievement (ranking 1-4) 
It should be noted that it was consciously considered that the children's assessment was not used for the analysis of the research data, because the traditional assessment still prevails in the schools. The authentic dynamic assessment has not been introduced yet: that is the future challenge to overcome. For most children with special needs, it was only the first year of their inclusion. Therefore, the official assessment data was not applied in this study.

As a result of mentoring, the teachers' learning is not the traditional way of acquiring new knowledge and skills; rather, they seek "wisdom" or "insight" together. Even more, insight - the teacher's ability to react to the particular learning needs of a particular child in a particular situation and in particular learning environment - is the most important benefit of the action research, and that was developed through collaborative learning and reflection (Figure 2).

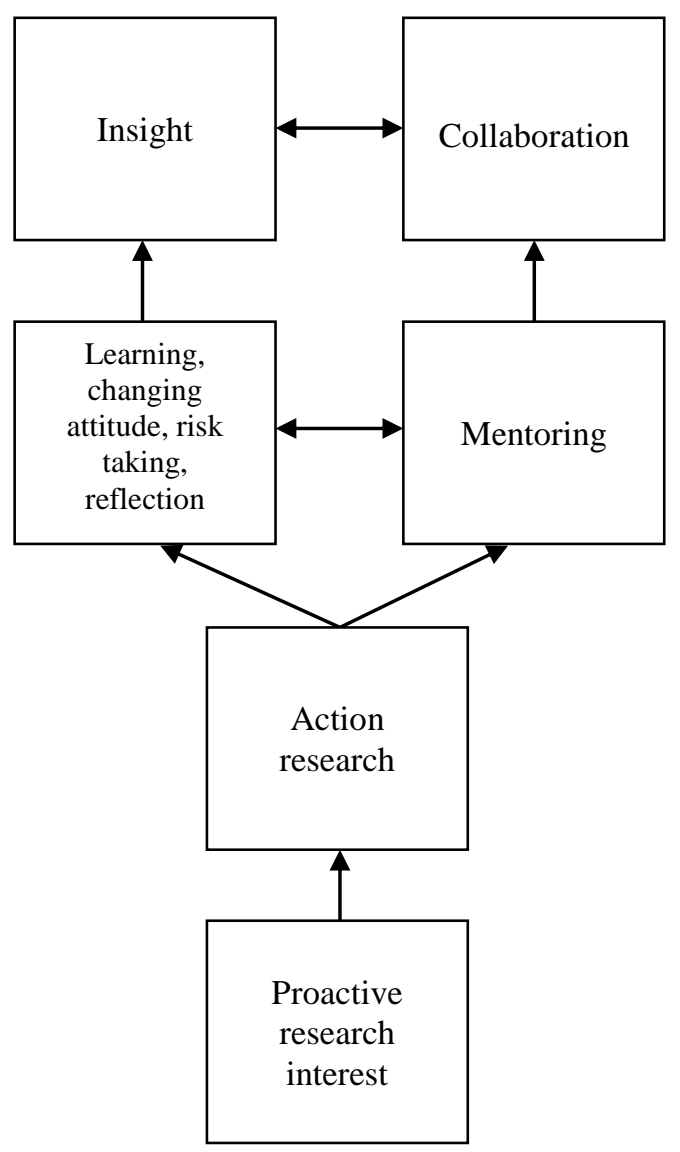

Figure 2. Scheme of the action research

Salite et al. (2009) characterize wisdom as "the ability to find solutions in concrete circumstances on the grounds of past experiences and a common target-orientation that would benefit majority" (pp. 27-28). This study illuminates the impact of mentoring on the majority of other teachers and staff: the mentors and the mentees become disseminators of their ex- 
perience and wisdom in their schools and broader. The mentoring programme was finished by the publication "How to teach concepts to children with special needs: Examples of best practices" (Zaķe \& Vērzemniece, 2010) where the participants of the study share their best practices generously.

To summarize, the interpretive analysis of the mentors and the mentee teachers' authentic assessment approves that the implementation of the mentoring programme combined with the action research method was optimal for reaching the aims of this study: to enhance inclusion of children with special needs, promote teachers' professional development and collaboration in the inclusive school context. This study justifies the proactive nature of action research, which is acknowledged by Ainscow (2003) and Howes, Davies and Fox (2008). The limited two year period of the action research and the present difficulties caused by the economical and financial crisis engender a reasonable concern about the sustainability of inclusive education in Latvia. However, the interpretation of data within this study approves that school-based mentoring as one of the forms of collaborative school culture may promote future development of schools where differences are welcome and respected, and the continuous professional development is an inner need of the teachers.

\section{Acknowledgement:}

This work has been supported by the European Social Fund within the Project "Support for the implementation of doctoral studies at Daugavpils University". Agreement Nr. 2009/014 0/1DP/1.1.2.1.2/09/IPIA/VIAA/015.

\section{References:}

Ainscow, M. (2003). Using teacher development to foster inclusive classrooms. In T. Booth, K. Nes \& M. Stromstad (Eds.), Developing inclusive teacher education (pp. 15-32). London: RoutledgeFalmer.

Bourke, P., \& Carrington, S. (2007). Inclusive education reform: Implications for teacher aides. Australasian Journal of Special Education, 31(1), 15-24.

Bricker, D. (1995). The challenge of inclusion. Journal of Early Intervention, 19, 179-194.

Bricker, D. (2000). Inclusion: How the scene has changed. Topics in Early Childhood Special Education, 20, 14-19.

Carrington, S., \& Robinson, R. (2004). A case study of inclusive school development: A journey of learning. The International Journal of Inclusive Education, 8(2), 141-153.

Dewey, J. (1963). Experience and education. New York: Collier Books.

Fibkins, W. L. (2002). An administrator's guide to better teacher mentoring. Lanham, MD: Scarecrow Press.

Florian, L. (2008). Special or inclusive education. British Journal of Special Education, 35(4), 192-254. 
Freire, P. (1997). A response. In P. Freire, J. W. Fraser, D. Macedo, T. McKinnon \& W. T. Stokes (Eds.), Mentoring the mentor. A critical dialogue with Paulo Freire (pp. 303330). New York: Peter Lang Publishing.

Fullan, M. (1998). Leadership for the 21st century - breaking the bonds of dependency. Educational Leadership, 55(7), 6-10.

Hamre, B., \& Oyler, C. (2004). Preparing teachers for inclusive classrooms: Learning from a collaborative inquiry group. Journal of Teacher Education, 55(2), 154-163.

Hargreaves, A. (1992). Contrived collegiality: The micropolitics of teacher collaboration. In N. Bennet, M. Crawford \& C. Riches (Eds.), Managing change in education: Individual and organizational perspectives (pp. 80-94). London: Paul Chapman Publishing Ltd.

Hargreaves, A., \& Fullan, M. (2000). Mentoring in the new millennium. Theory into Practice, 39(1), 50-56.

Howes, A., Davies, S. M. B., \& Fox, S. (2009). Improving the context for inclusion: Personalising teacher development through collaborative action research. London: Routledge.

Jonson, K. F. (2008). Being an effective mentor: How to help beginning teachers succeed (2nd ed.). Thousand Oaks, CA: Corvin Press.

Knowles, M. S., Holton III, E. F., \& Swanson, R. A. (2005). The adult learner (6th ed.). Burlington, MA: Elsevier.

Lebeer, J., Sonnesin, G., Roth, M., \& Pokorna, V. (2006). Shortlist of programs, methods and approaches that activate cognitive development: List of criteria. In J. Lebeer (Ed.), In-clues: Clues to inclusive education (pp. 67-70). Antverpen-Apeldoorn: Garant.

Nīmante, D. (2008). Iekḷaujošās izglīīibas izpratne Latvijā [Understanding of inclusive education in Latvia]. Proceedings of the ATEE Spring University Teacher of the 21st Century: Quality Education for Quality Teaching (pp. 433-441). Rīga: Latvijas Universitāte.

Reason, P., \& Bradbury, H. (2008). Introduction to groundings. In P. Reason \& H. Bradbury (Eds.), The Sage handbook of action research: Participatory inquiry and practice (pp. 1-10). London: Sage Publications Ltd.

Salīte, I. (2009). Ilgtspējīga izglītība demokrātijas un darbības pētījuma skatījumā [Sustainable education from the perspective of democracy and action research]. Skolotājs [Teacher], 1(73), 8-13.

Salīte, I., Gedžūne, G., \& Gedžūne, I. (2009). Educational action research for sustainability: Seeking wisdom of insight in teacher education. Journal of Teacher Education for Sustainability, 11(2), 14-30.

Salīte, I., Mičule, I., Kravale, M., Iliško, Dz., \& Stakle, A. (2007). Toward the sustainability in teacher education: Promise of action research. In A. Pipere (Ed.), Education and Sustainable Development: First Steps toward Changes (Vol. 2, pp. 263-292). Daugavpils Universitāte: Akadēmiskais apgāds ,Saule”.

Schein, E. H. (2004). Organizational culture and leadership (3rd ed.). San Francisco, CA: Jossey-Bass.

Scruggs, T. E., Mastropieri, M. A., \& McDuffie, K. A. (2007). Co-teaching in inclusive classrooms: A metasynthesis of qualitative research. Exceptional Children, 73(4), $392-416$. 
Tillman, L. C. (2005). Mentoring new teachers: Implications for leadership practice in an urban school. Educational Administration Quarterly, 41(4), 609-629.

Vigotskis, L.. (2002). Domāšana un runa [Thinking and speech]. Rīga: Eve.

Wang J., \& Odell, S. J. (2002). Mentored learning to teach and standards-based teaching reform: A critical review. Review of Educational Research, 72(3), 481-586.

Wildman, T. M., Magliaro, S. G., Niles, R. A., \& Niles, J. A. (1992). Teacher mentoring: An analysis of roles, activities, and conditions. Journal of Teacher Education, 43(3), 205-213.

Zaķe, D., \& Vērzemniece, L. (Eds.). (2010). Kā mācīt jēdzienus bērniem ar īpašām vajadzībām: labās prakses piemēri [How to teach concepts to children with special needs: Best practice examples]. Jēkabpils: IIC.

\section{Correspondence:}

Dr Ženija Bērziņa, Daugavpils University, Faculty of Education and Management, Daugavpils University, Parādes Street 1, LV-5401. Email: zenijab@tvnet.lv 